\title{
Impediments to Implementation of Peace Education in Public Universities In Kenya.
}

\author{
Dr Mrs. Esther Chelule, \\ Egerton University, Kenya
}

\begin{abstract}
Peace education is an elusive term that has defied many scholars' definition. It has been defined variously because it carries different meanings to different people. Peace education dates back to $19^{\text {th }}$ century after the horrors of the two World Wars and has evolved through many levels as club to finally as an education programme. The paper discusses the impediments to implementation of peace education in Kenyan public universities. The researcher used library research by surveying on the research findings in books, journal, and internet The literature covered information on background information of Peace Education, definition, historical background, United Nations recommendation for peace education and how peace can be achieved through education. Research design adopted the Integrative Theory of Peace (ITP) by Danesh, H,B., (2006). The study makes recommendations and further suggestions for further research.
\end{abstract}

\section{Introduction}

As we come to celebrate 50th years of scholarship and development in Africa, it is with great pride and joy for our achievements .however, we have some mixed feelings that we could achieved more than what we have, of having lost some precious time waiting for things to happen on their own way, but never did. We also hoped to achieve peace and development without having to work for it, but it never did. There has been war and untold miseries due to advancement of technology which has caused destruction to lives and environment. The world today is a state of more fear than confidence than the previous generation. Peace is an essential ingredient in our society today so as to achieve education and development goals, transmit values to our next generation and create a friendlier environment of peace and love. We need peace in institutions of higher learning, we need peace in our nation, and we need peace in the world today, more than ever.

I concur with Federico Mayor, when he put it:

'Peace is possible for life at all stages and it is up to man to choose his destiny or to suffer from the horrors of war. Today mankind is at the crossroad where he has to choose with courage, determination and imagination. Federico Mayor, (www.hagueapeace.org)

While "Peace is the only battle worth waging" Albert Camus (1913 - 1960), author, journalist and playwright. Education indeed, over the years has transformed and developed societies into civilized entities. Scholars in Africa today have the golden opportunity to develop the Continent, and transform it through education. Indeed UNICEF uses the term Education for Development to describe an approach to teaching and learning which aims at building commitment to global solidarity, peace, acceptance of diversity, social justice and environmental awareness in young people (Fountain, 1995).

John Dewey, the philosopher and educationist put it:

".Education has been closely connected with the development of

Civilizations and has always been viewed as a way of bringing

better life into existence... The evolution of the society depends upon it.

This is as true today as it has ever been.... (Dewey, 1943)" Tsion, et al, 2006, p4).

\section{Definition of Peace Education}

Definition of peace is elusive and there are many definitions as are the individuals defining it. Peace comes from Latin word, pax, which denotes contractual relationship implying recognition and agreement with human relationship. Peace education has been defined variously by various scholars.

UNICEF an advocate of education for peace defines Peace Education as:

A process of promoting the knowledge, skills, attitudes and values needed to bring about behaviour changes that will enable children, youth and adults to prevent conflict Peacefully, and to create conditions conducive to peace, whether at intrapersonal, Interpersonal, inter-group, national or international level (www.unicef/educ.org). 
UNICEF definition of peace and peace education programme development makes the basic assumption that education can promote globally peaceful resolution and prevent violent conflict at all levels whether at interpersonal, societal, overt or structural. Education for Development is the term used in UNICEF to describe an approach to teaching and learning which builds a commitment to global solidarity, peace, acceptance of differences, social justice and environmental awareness in young people (Fountain, 1995).

While Laing, R.D. (1978), indicates that there is no universal definition of peace education, he gave a definition of peace education as an attempt to respond to problems of conflict and violence of different magnitude, which ranges from the global, national and personal level, exploring ways of the creation of a more just and equitable futures. This definition echoes Albert Einstein's who put it that peace is not merely the absence of war (Johan Galtung's concept of negative peace) but instead the presence of justice, law of order, that the presence of a government (Hicks, 1985).Reardon (1988) indicated that peace is the absence of violence in all its forms, whether physical, social, psychological and structural. It is the examination of nature of causes, reasons, goals of war so as to find possible ways of reaching human goals without resorting to use of force, and uncover the possible conditions of peace. (O'Kane, 1992). Since there is no universal definition of peace education, many theorists therefore focus their attention on its purpose and content instead of defining it.

Harris (2004) contends that there is no universal definition of peace education. Peace education therefore is a generic term that subsumes; various kinds of education among them are nuclear Age education, a bomb education disarmament education. Peace educations, to other scholars, include education for international understanding, political education, and global education. The purpose of education is generally for the promotion of development .of consciousness of the planet which enables people to work as global citizens and changing the current mode of thought and human condition and structures (Reardon, 1988, cited in Catholic Education Office \& NSW Dept of Education) .It includes cross-disciplinary study, re-examination of the available subject methodologies, school structures, and concern on the content style of teaching, both formal and informal. The definition has drawn various departures and overlap in the understanding of peace education. Peace Education is more effective and meaningful when contextualized in a social setting of the needs of a particular country but also ensured to be globally relevant (Mayo (2001).

Some of the salient features and characteristics of peace education is that it is holistic, that is, it encompasses the "physical, emotional, intellectual, and social growth of children within a framework deeply rooted in traditional human values. It is based on philosophy that teaches love, compassion, trust, fairness, cooperation and reverence for human family and all life on our beautiful plan. Peace education is also skill building for it empowers children to be creative and non destructive in the ways in which settle conflict and live in harmony with themselves, others and their world (Fran Schmidt and Alice Freidman,1988).Thus peace education is remedial measures to protect children from falling into the ways of violence in society.

Salomon, (1999), cited by Maxwell) rejects much of the characteristics of peace education, claiming that such programmes are nothing but precursor to genuine peace education. There are many things called peace education which range from the reduction of violence in schools, studies of war and peace, moral, value education, to cultivation of self esteem. Peace education therefore is not on interpersonal conflict, but it is wider which includes ethnic (which may be religious, racial or national) hostilities interspersed with inequalities in development, and a long history without a promising future. Peace education though it has immediate aim, it is a long term investment (ibid).

Harris (2004) identified five postulates of peace education summarized below as follows:

1. Peace education explains the root causes of violence.

2. Teaching of alternatives to violence.

3. Adjustment to cover violence of different forms.

4. As a process peace varies contextually.

5. Peace is ubiquitous, present everywhere.

\section{Goals of Peace Education}

According Harris there are ten goals of peace education. These are: Appreciation of the richness of peace as a concept, address of fears, provision of information about security systems, understanding violent behavior, developing intercultural understanding, provision of future orientation, teach peace as a process, promote a concept of peace accompanied by social justice, stimulate respect for life and end violence.

There is a consensus, however, that peace education includes conflict management, communication diversity, self-esteem and environmental awareness. It is generally agreed that peace education fosters changes which make the world more human and a place worth living. It eradicates injustices, inequality, prejudices, intolerance abuse of human rights, environmental destruction, violent conflict, and war .It also reflects the political as well as societal economic agenda prevalent in the society by challenging the present evils committed which peace education wishes for a change (Vriens, 1990). There is also an agreement that peace education is the acquisition of peaceful and appropriate behavior in the community which is perceived to be relevant to their goals. Burney 
J. (Catholic Education .O. NSW) indicated the basis of peace education is not only on what is taught but on respect for children as people, acceptance of their ideas, their feelings of a secure classroom environment and trust of the teachers and their classmates. Peace education is not to be described as a distinct "subject" in the curriculum, separate into all quality of education but as process mainstreamed into other subjects.

\section{History of Peace education}

Peace promotion and avoiding violence dates back to the Biblical days of the Old Testament teachings of Prophet Moses, Jesus Christ, and other world religious leaders. In Europe peace education is found in the works of Czech Educator, Comenius, (1642) who in his booklet Agelus Pacis urged for "education for moderation and love", that indeed it was crucial for the world to be at peace, which can only be found through universal sharing of knowledge. It was after American Civil War that the universities got concerned that peace was essential, especially after witnessing the wanton destruction of lives and property, untold misery and loss brought about by the application of sophisticated, deadly weapons. As a result, students formed Peace clubs and societies and started travelling from campus to campus in America, campaigning against war, and lobbying for peace education. This initiative helped promote the League of Nations which was mandated to end war. These peace societies had the first peace convention on 18th May1899, in The Hague, Netherlands, which became the Peace Day henceforth. The Hague World Conference in 1907 made a powerful appeal in an attempt to put limitations on war, which further gave rise to more peace activists.

After World War I, they promoted and lobbied for peace education, through "education for International understanding on varying cultures and politics; however the degree programmes in the university had not been started. In 1912, School Peace League in the USA campaigned and made it mandatory for every state to offer chapters promoting international justice in schools. The World War II generated new focus on education for "education for world citizenship" because of the politics among the super powers who were then USA and the Soviet Union. The United Nations, around this time was created to stop the scourge of war in the world which could only be done by having peace education. The origin of peace education in UN precinct, thus dates back to 1945, when the United Nations was established to save succeeding generations from the scourge of war, to reaffirm faith in the dignity and worth of human person in the equal rights of men and women, to establish conditions under which justice and respect for the obligations arising from the treaties and other sources of international law can be maintained .Preamble, UN Charter, 1945

UNESCO defines peace education with 6 pillars: freedom, equality, solidarity, tolerance, respect for nature, and shared responsibility. UNESCO which had then been newly formed took the initiative to encourage peace through the advocacy for change in attitude of the people and stated thus: "since wars begin in the minds of men, it is in the minds of men that the defenses of peace must be construed". The focus was therefore on peace education around the world. In 1953, UNESCO sponsored School Project to investigate the salient features in schools around the world and identified six objectives such as the improvement of the teachers' teaching capacity on world problems; the young people to have increased awareness of world problems; equip youth with skills for solving such problems; develop effective methodologies and materials be developed to teach world problems: disarmament, economic order and human rights ; indicate how issues can be studied in the world countries and ; ability to understand world's problems and ways of getting and identifying solutions by knowing views and opinions of other people.

In 1948 Manchester Liberal Arts College in Indiana became the first to develop peace studies academic programme, sponsored by Brethren Church. In 1949, Herbert Read argued that arts and peace education should be merged so as to motivate individuals to promote peace. . For instance Peace studies courses were offered in Manhattan Catholic College, New York city in 1968, and in Colgate University in upper New York State begun in 1969. The Quakers Project in 1974, published curriculum for teachers in New York, which had 25 editions and translated to 7 different languages.

In India, Gandhian studies, at about the same time, focused on non-violence, promoted by university professors and scholars, which had the aim of inculcating values of non-violence in the minds of young people. In the 1960s, Peace Research Institutes were started in Europe however they had no formal peace studies courses. The impact of Vietnam War led to the establishment of peace programmes in university and colleges, with an international focus due to the threat of nuclear in the world .Some few campuses offered courses related to Vietnam War begun in the 1970s. In 1973, in England peace studies were begun in Bradford University.

In 1980s, there was exponential growth of colleges and campus which offered peace studies because there was more fear and threat of the use of nuclear weapons none was sure of the fate of the planet. By mid 1980s courses on peace studies focused on International conflict and nuclear threat in western Europe and North America. By the end of $20^{\text {th }}$ Century in North America campuses peace studies courses focused on the impact of political and social violence, causes of violence and how to resolve them. Students were equipped with skills on how to transform their society from various threats brought by environmental degradation, violence and conflict management without resorting to violence. 
This is the period which witnessed the writings of various scholars and hence the three books which were published one in Norway, and two in The USA which helped in the development of reference materials. The books were: Education for Peace, by Norwegian Birgit Brocks-Utne (1985); and Comprehensive Peace Education authored by Betty Reardon (1988), and Peace Education by Harris, (1988).

The end of the Cold War saw a paradigm shift in peace studies courses in the universities which was mainly international politics, to local emerging issues, like structural, domestic and civil violence and also on international, national and individual security, and shift in focus from negative peace to positive peace.

\section{Distinction between peace education, peace studies and educating for peace}

The terms are at times used interchangeably but many scholars tend to see a distinction in the terms. Peace education, according to Maxwell A., (2000) is broader than peace studies, which is used to describe specific courses, units, research projects on war or issues of peace at tertiary levels but peace education is more inclusive. Peace education includes interdisciplinary study, which involves the re-examination of existing curriculum both formal, informal, hidden, subject methodologies, school structure, content and teaching styles consistency. This definition however seems to depart with the definition of Muller and Kings (2006), who defined peace education as a sub-field of peace studies which seeks to engage persons capable of including peace-related content in curriculum at whatever educational levels. Peace education utilizes culture, arts with its tolls -music, drama, dance, paintings, and sculpture (Johnson,T,\& Johnson D.W (2005)

Muller (2006) further indicates that Peace Education is the broadest sub-field of peace studies which involves teaching and learning about values, attitudes and forms of behaviours and reflects respect for life, human beings and peoples and their dignity and for all human rights. It also include the rejections of violence and in all its forms and commitment to the principles of freedom, justice, solidarity, tolerance and understanding among peoples and between groups and individuals cite education is a major tool that can be used to inculcate values, attitudes, knowledge and changing behaviour to a desired response.

Peace education brings together multiple traditions of pedagogy, theories of education, and international initiatives for the advancement of human development through learning. It is dynamic, interdisciplinary, and multicultural and came into practice through the persistent great works of such prominent educators such as John Dewey, Maria Montessori, Paulo Freire, Johan Galtung, Elise and Kenneth Boulding, among others. Peace education is built on the principles and practices that have evolved over time, and at the same time, responding to different historical circumstances with an aim of cultivating the knowledge, skills and attitudes needed to achieve and sustain a global culture of peace. Peace is understood not only as the absence of traditional forms of direct violence, but also as a positive presence. Education is a key tool in combating poverty, in promoting peace, social justice, human rights, democracy, cultural diversity and environmental awareness. Educating for and about all aspects of peace constitutes peace education (United Nations Cyberschools, 2012)

Education for peace (www.educationforpeace.noenglish, is about creating a culture for peace and implies an active concept of peace through values, life skills and knowledge in a spirit of equality, respect, empathy, understanding and mutual appreciation among individuals, groups and nations (Brahm,2006). Education for Peace (EFP) is a school program that creates violence-free and peaceful school environments which is which the following are met: emotional, social, and intellectual needs of diverse school populations, with interrelated components of unity in diversity. Peace is based on the fact that peace and education are inseparable aspects of civilization. No civilization is truly progressive without education and no education system is truly civilizing unless it is based on the universal principles of peace.

Many scholars have preferred to use the term educating for peace which is seen as highlighting the need for harmony between content and processes of teaching, showing how the teacher promotes peace through the creation of a friendly atmosphere in classroom (free from caning), removal of unhealthy competition in class, passive learners and lack of dialogue between the teacher and the learners. The term therefore, educating for peace is seen as making clear proper articulation of teaching methods, content to ensure cooperation, active participation, dialogues as well as positive peace which is cultivated by the teacher for learners in the classroom through learning activities. Scholars feel that it is important for teachers to avoid aggressiveness in classroom so that learners can see peace in action. Education for Peace has three interrelated components of peace education in a triangle form, consisting of knowledge, skills and attitudes as given diagrammatically below as follows:

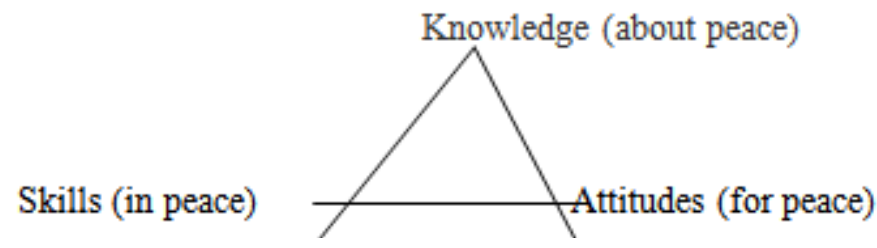


Knowledge for peace encompasses all facts that should be included in the school curricula, such as information on disarmament, the environment and sustainable development, human rights, cultures , military consumption and alternative mechanism of conflict management( Brahm,2006). The second component is skills for peace which it incorporates communication, conflict management skills, crisis analysis, prioritization, verbal and written reporting skills, teamwork skills which are learnt through various methodologies of education daily activities in school, planned training. The third component of peace education is attitudes for peace such as solidarity, curiousity and appreciation and being interested in the other, willingness to enhance democratic solutions, justice and equality. These are achieved by open debate and educational methodologies (www.educationforpeace.noenglish .

Education for Peace then, is a conceptual framework which is guided by the recognition that each member of the global society is bound by principles relating to human welfare, such as justice, liberty, responsibility, equality, dignity, security, democracy and solidarity; each member of society is an active participant in a local community and is in turn committed to a global harmony reflective of the diversity of the human population; each member of the global society must act individually and communally toward guardianship of our world as a whole, guaranteeing the right to a sustainable future(Brahm,2006).The implementation of this conceptual framework recognizes the practice of peaceful relations at all levels: personal, familial, communal, inter-cultural and global. It entails a process of knowledge acquisition and skill-building which affects the behavior of individuals and groups and provides a model for the formal and informal curriculum of the school.

Education for Peace is a process and condition which permeates all aspects of school life, with implications for learners, teachers, and administrators and it extends beyond the school to society as a whole. It is a conceptual framework where schools design program including the dissemination of universal values, attitudes, and the development of skills for enabling learners be part of the global participants (www.isa.school.org/education ). Peace education is based on a philosophy that teaches nonviolence, love, compassion, trust, fairness, cooperation and reverence for the human family and all life on our planet. Skills include communication, listening, understanding different perspectives, cooperation, problem solving, critical thinking, decision making, conflict resolution, and social responsibility. Peace education in short, leads to peaceful living.

\section{Underlying value assumption}

UNICEF makes important assumptions on peace education which include the following: the peaceful resolution of conflict and prevention of violence, whether interpersonal or societal, overt or structural, is a positive value to be promoted on a global level through education. Another assumption is that this value may not be universally shared by all individuals and groups, and in all circumstances. The rationale for such programmes is that peace is essential for children's survival, development, protection, and participation in society. Violence and armed conflict are major barriers to the realisation of children's rights on all levels. The promotion of peace, and of peace education, is therefore an essential component of UNICEF's mandate to work for the rights and well-being of children. Developing a peace education initiative with community involvement from the outset may help keep the focus on the creation of a harmonious and rights-respectful society, allay concerns about any politically motivated aims, and help to clarify the values of all stakeholders. UNICEF views Peace Education as the process of promoting the knowledge, skills, attitudes and values which brings change , which in turn enables children, youth and adults to prevent conflict and violence, both overt and structural, to resolve conflict peacefully, and to create a conditions conducive to peace, whether at an intrapersonal, interpersonal, intergroup, national or international level (www.unicef.org/edu/eng) .

Peace Education that was developed by UNICEF envision quality education for all learners, hence a need for focused goal whereby all educators focuses on and thus by achieving it achieve peace education. This vision lead to a declaration in 1990 called World Declaration on Education For All (EFA) (Jomtien Declaration). The Declaration indicates that basic learning comprise of literacy, numeracy, knowledge, skills, attitudes and values are tools required to live and work in dignity and be able to participate fully in development . These needs can be satisfied by promoting social justice, acceptance of differences and peace (inter-Agency Commission, WCEFA, 1990)

UNICEF describes peace education as schooling and other educational initiatives that:

- Function as 'zones of peace', where children are safe from violent conflict

- Uphold children's basic rights as outlined in the Convention of the Rights of Child (CRC)

- Develop a climate that models peaceful and respectful behaviour among all members of the learning community

- Demonstrate the principles of equality and non-discrimination in administrative policies and practices 
- Draw on the knowledge of peace-building that exists in the community, including means of dealing with conflict that are effective, non-violent, and rooted in the local culture

- Handle conflicts in ways that respect the rights and dignity of all involved

- Integrate understanding of peace, human rights, social justice and global issues through the curriculum whenever possible.

- Provide a forum for the explicit discussion of values of peace and social justice

- Use teaching and learning methods that stress participation, Cupertino, problem-solving and respect for differences

- Enable children to put peace-making into practice in the educational setting as well as in the wider community

- Generate opportunities for continuous reflection and professional development of all educators in relation to issues of peace, justice and rights. (Peace Education in UNICEF Working Paper Series, July 1999).

\section{Culture of Peace}

The term "culture of peace" was initiated by cultura de paz, and educational initiative in Peru(1986), and by Seville Statement on Violence(1986) and was adopted by scientists around the world, which stated that war is not a fatality determined by genes, violent brains, human nature or instincts, but is rather a social intervention. Therefore "the same species that invented war is capable of inventing peace" (Seville Statement :), (www.unesco.org/cp). UN General Assembly in 1998(resolution A/52/13),defined the Culture of Peace as a set of values, attitudes and behaviour that rejects violence and endeavour to prevent conflict., that addresses the root causes, with a view to solving problems through dialogue and negotiation among individuals and groups and nations. UN and UNESCO were founded to bring peace in the world where peace which is more than a more than absence of war, but justice and equity for all as the basis for living together in harmony and free from violence, and for future children and succeeding generation. In the year which followed, that is 1999, the UN Declaration and Programme of Action on a Culture of Peace (resolution A/53/243) called all to resume the responsibility. This included the civil society, media, parents, teachers, among others.

The Report to UN General Assembly (2001, A/56/349) the UN Secretary General, emphasized two major aspects to which members states must commit themselves during the decade: education for a culture of peace with children at the centre; and an organization strategy sustaining a global movement, which begun during the International Year 2000, which emphasized strongly on partnership and information technologies. The Year 2001-2010 was therefore declared an International Decade for Culture of Peace and Non-Violence for the children of the world. This was indeed a move aimed at translating the declaration through education for the achievement of quality and a well- grounded universal values and practice of a culture of peace and nonviolence (www.unesco.org/cpp/uk/declaration/sevile).Matsuura (2001) concludes "peace can be at hand; it is in on our hands. Today, more than ever a culture of peace".

(UN General Assembly (resolution A/52/13). The UN Second Special Sessions on Disarmament put it that although arms control and disarmament are legitimate unit areas for study in the classroom, peace education should not be seen as relating exclusively to these issues, because peace education is broader than study of risks of nuclear war.

The Culture of Peace by UNESCO identified eight Action areas were also rolled out for actors at the national level, regional and international levels as follows:

1. Fostering a culture of peace through education by promoting education for all, focusing on girls specifically, revising curricula to promote the qualitative values, attitudes and behaviour inherent in a culture of peace training for conflict prevention and resolution, dialogue, consensus building and active non-violence.

2. Promoting sustainable economic and social development by targeting the eradication of poverty, focusing on the special needs of children and women, working towards environmental sustainability, fostering national and international cooperation to reduce economic and social inequalities.

3. Promoting respect for all human rights by distributing the Universal Declaration of Human Rights at all levels and fully implementing International instruments on human rights.

4. Ensuring equality between women and men by integrating a gender perspective and promoting equality in economic, social and political decision- making, elimination of all forms of discrimination and violence against women, supporting and aiding women in crisis situations resulting from war and all other forms of violence.

5. Fostering democratic participation by educating responsible citizens reinforcing actions to promote democratic principles and practices; establishing and strengthening national institutions and processes that promote and sustain democracy. 
6. Advancing understanding, tolerance and solidarity by promoting a dialogue among civilizations, actions in favour of vulnerable groups, migrants, refugees and displaced persons, indigenous people and traditional groups, respect for differences and cultural diversity.

7. Supporting participatory communication and the free flow of information and knowledge by means of such actions as support for independent media in the promotion of a culture of peace, effective use of media and mass communications, measures to address the issues of violence in the media, knowledge and information sharing through new technologies.

8. Promoting international peace and security through action such as the promotion of general and complete disarmament, greater involvement of women in prevention and resolution of conflicts and in promoting a culture of peace in post-conflict situations, initiatives in conflict situations, encouraging confidence building measures and efforts for negotiating peaceful settlements... peace is in our hands.

\section{Peace Curriculum}

"If peace is both the destination and the journey then what we teach and

how we teach it must not be separated in our preparations for working with pupils". Patrick Whitaker, British educational advisor and former teacher,

The term "curriculum" is derived from Latin word curriculum which means "the course or circuit that a race is to follow, it implies the path or track to be followed or the course of study to be undertaken" (Kothari C.R. (1985), Barrow, 1982 cited by UNICEF). However various scholars have defined curriculum in various ways depending on how they understand the term. Some of the definitions of curriculum are:

"Curriculum is a way of talking about what we want students to learn" (Furniss, 1999, cited by UNICEF); it is the organization of teaching and learning "(Moyles, Hargreaves, \&Moyle, 1998, cited by UNICEF). UNICEF has developed 21 principles of to design curriculum which form the basis for most developing curriculum. Developing a peace Education curriculum has been seen not only as a series of ideas or lesson plans but also as a methodology and way of being. The Hague peace education (www.haguepeace.org/rsources) indicates that peace education curriculum pays much attention to the methods, values and skills of learning and also teaching for ands about peace, instilling and encouraging trainers and teachers or facilitators to domesticate the content to the local culture under which it is offered.

Hence,

"Pedagogy is the determinant of human relationships in the educational process.

It is itself the medium of communication between teacher and learner, and that aspect ...

Which most affects what learners receive from their teachers."

Reardon, B., (1988, cited by Harris, I., (2003)

The practice of peace education is an opportunity to promote the total welfare of students, advocate for their just and equitable treatment of youth, and promote individual and social responsibility for both educators and learners. Through pedagogy and social action, peace educators demonstrate that there are alternatives to violence (UN Cyberschool/peace, 2012).

Monisha B., (2004), put it that the differing in meanings of the term peace has led to differing forms and types of peace education such as:

- International education or global peace education. The horrors of the WW II caused the countries to promote internal justice and fraternity and helping students avoid war, based on teaching of Comenius, peace educator of Moravia.

- Human rights education or violence prevention programme: This was as result of the establishment of International Criminal Court and international organizations, Universal Declaration of Human Rights (1948) to address violent issues, dignity for all reduction of stereotypes.

- Development education: This was begun by Johan Galtung, Norwegian peace education scholar who distinguished between negative and positive peace, while Brazilian educator, Paulo Frere advocated for the address of the source of people's oppression and oppressive conditions , "Conscientization" or process of understanding, and promotion of poor people's involvement in planning instead of top-down development. Martin Luther and Mahatma Gandhi and all non-violent activist used to resolve conflict

- Environment education or non-violence education: Global warming, extinction of species and pollution due to previous belief that resource was infinite. Peace education became more concerned to teach environmental conservation, reduction of destruction and habitat preservation.

- Conflict resolution education of conflict resolution program: This was Montessori's discouragement of authoritarian pedagogy, and promotion of structured curriculum and education which liberates the child's spirit to love others. This helped understand dynamics of war, especially after the Vietnam War.

The past experiences in a particular culture and environment influence the development of curriculum. For instance, in Japan peace education is equivalent to anti-nuclear bomb education because of the devastating 
effects and horrors caused by the bomb at Hiroshima and Nagasaki .The methodology of teaching such a peace education curriculum is for the teachers, who were victims and survived the A-bomb attack, live to tell the horrific experience of bomb of August 1945." - Okamoto, M., Japanese peace educator (unescopeaceeducation). Harris, I., (1988) developed a peace education training programmes in schools and emphasized that peace education should not be thought as a subject in curriculum but as a mainstreamed into educational experiences. Report by a working Committee on Peace Education for Africa (2006) identified following eight components of peace education curriculum. These are Human Rights Education, that is the rights of the child and women, enshrined in the Universal Declaration of Human Rights, civil and political rights, respect for elders, etc.; Education for Social Justice, covering such issues as globalization, fair trade, poverty, gender \& development, gender equity; Multi-cultural Education, and issues including cultural and racial prejudice, stereotypes and discrimination, tackling problems of language and ethnicity; Sustainable Development Education, which covers health issues, human security, environment degradation, sustainable ways of living; Governance \& Leadership Education, and its accompanying issues like democracy, citizenship, civics, electoral process, participation, civil society, media; Personal \& Inner Peace Education and such qualities such as self confidence, inter-personal qualities, compassion ; Gender Education, for instance gender roles in peace building and gender equity and ; Education for Non-violent Conflict Transformation which involves non-violence, effects of war, conflict resolution, conflict management, mediation, etc.

\section{Non-violence Education}

Non-violence is a philosophy or a strategy rejecting the use of violence, a belief that using violence is inherently wrong. Nonviolence encompasses many techniques for seeking truth and justice through the application of power in conflict without using physical violence. It is also a holistic theory and practice that resolves conflicts in a constructive manner by rejecting the use of aggression and violence (Matsuura, 2001).

At the second International Forum on the Culture of Peace, held in Manila (Philippines), in November 1995, UNESCO formulated a number of proposals aimed at strengthening a culture of peace through education. Two of these advocate a redesign of the teaching of history in such a way that violence and war no longer featured as the only means available to individuals or nations for defending their freedom and achieving justice. These proposals made were such that teaching programmes should incorporate awareness of issues on social movements (national and international), which is geared toward peace and non-violence, democracy and equitable development. It was also proposed that there should a systematic review of the way history is taught so that it is reformed to emphasis on non-violent social change, and the contribution of women to non-violence. Children should admire heroes not as individuals who have been great warriors or revolutionaries who have made themselves famous by fighting but individuals who have defended the cause of non-violence and peace.

UNESCO enhances knowledge of insight into basic concept of peace and non-violence in many regions and countries around the world in the text Non-Violence in Education., reflected in the Declaration for The Decade beginning of the United Nations' International Decade for the Culture of Peace and Non-Violence for the children of the World (2001-2010), with the major tasks throughout the decade to promote the teaching of the practice of peace and non-violence. Non-violence is promotion and defending freedom, justice and peace.

\section{Peace Education Theory}

In 1975, Johan Galtung suggested that there is no theory for peace education and hence an urgent need to get such a theory. Danesh, H, B., (2006) proposes the Integrative Theory of Peace (ITP) and briefly outlines the education for peace curriculum (EFP). ITP is based on the concept that peace is, at once, a psychological, social, political, ethical and spiritual state with its expressions in intrapersonal, interpersonal, intergroup, international, and global areas of human life. The theory holds that all human states of being, including peace, are shaped by our worldview our view of reality, human nature, purpose of life and human relationships. Four prerequisites for effective peace education, there should be focus on unity-based worldview, culture of healing, culture of peace and peace-oriented curriculum. (http://e.wikipdia.org/peace_education)

\section{Peace Education in Schools and Universities}

Many countries of the world surveyed by UNICEF reported that peace education is integrated in the curriculum of established subjects. Bar-Tal (2002) indicated that educating for peace programmes differ from country to country because of differing terms like ideology, objectives, emphasis, curriculum content and practices. The following countries are examples of some countries offering differing peace education but with differing content and emphasis. In Australia, peace education is concentrated on challenging ethnocentrism, cultural chauvinism and violence and on promotion of cultural diversity, nuclear disarmament and conflict resolution, while in Japan peace education is referred to as A-Bomb education because of the Atomic bomb dropped at Hiroshima and Nagasaki which caused untold devastation. Peace education thus focuses on nuclear disarmament, militarism and nature of responsibility for acts of violence performed in the past. 
In South, Latin America and Africa where poverty is a structural violence, peace education is focused on structural violence, human rights and economic inequalities or development education. USA's peace education is on prejudice, violence and environmental issues. In India it is referred to as Gandhian studies. In Scandinavian countries because of their concern on arms race and extreme cost of arms, it is called disarmament education. In Ireland, peace education is called "education for mutual understanding" due to catholic Versus protestant conflict (Harris, 2004), while in South Korea, peace education is referred to as "reunification education". This variation in understanding the term peace has led some scholars to use the term conflict resolution because peace education is indeed an effort to identify strategies of resolving conflict.

For instance, Egypt has integrated human rights, life skills, gender issues and environment in their curriculum.

In Nigeria, Peace Education program is designed to address the rising level of child and youth involvement in deadly conflicts, either as actors or as victims of source-based, economic and political conflicts. In Liberia, Christian Health Association of Liberia (CHAL) teach conflict management, while Mauritius ,Caribbean and Madagascar with multiracial multi-ethnic and multi-cultural have no history of violence but have lived in harmony, peace and stability and therefore see no reason for establishing peace education, unless for future prevention. Malaysia \& Philippines have, in their curriculum peace education offered in subjects like Value education, Citizenship Education or development Education. In Sri Lanka Education for Conflict Resolution is provided with a goal of creating an attitude of tolerance, understanding and non-violence methodologies. Mauritania does not have peace education in their curriculum. In Afghanistan the teaching of peace education is modified and made to be friendlier by replacing in their textbooks the contents which have been glorifying war, for instance replacing the use of knives with apples in counting mathematics. However, nationalism has been an obstacle to adoption of peace education. In Turkey, a principle of Ataturk which means "peace at home, peace in the world" written in Turkish language. In West Bank and Gaza Strip Peace Education is integrated into religious education, languages, sciences, social studies and mathematics while in Haiti life skills has component of peace education as it emphasizes personal skills. In Guyana Peace Education is implemented under UNICEF as a Project which put a lot of emphasis is on racial tolerance, reduction of prejudices, problem solving and conflict resolution. Cambodia promotes peace and conflict resolution through stories about the value of love for others, neighbours, tolerance for minority as well as respect for family and school members. In Haiti peace education is incorporated in Life Skills which help in development of personal skills of conflict resolution. Burundi integrates Peace Education and learning methodologies into subjects, for instance, Mathematics, language, sciences, environment, music and sports. The aim of Burundi's peace education is to promote human rights and duties, peaceful conflict resolution and social assistance administered to children traumatized by war. Rwanda focuses their peace education on addressing such issues as refugee returnees, displaced children. Somalia experiences challenges with the provision of peace education in conflicttorn and emergency environment, but UNESCO-PEER programme is active in trying to bring peace education to the people.

\section{Peace Education in the public Universities in Africa}

In Africa at the Horn of Africa has been a zone of incessant zone of conflict and instability which vary from social, economic, political, identity-related and resource-based. This has accounted for over 6 million of the world's 13 million refugees in 1996 alone. The universities play a major role in promoting a culture of peace through existing teaching programmes that are appropriate peace-related modules and subjects like political science, history, sociology, psychology, education, law, among others. Kwakwa, E. (1977). Kwakwa (1977) further states that African Centre for the Constructive Resolution Disputes (ACCORD) has compiled modules on Peace education courses in 30 universities in Southern Africa and sub-regional. The ACCORD is associated with black South African universities have 3 years undergraduate courses in conflict studies. Research is boosted by UNESCO's Culture of Peace in South Africa's Durban-Westville, and in Cocody in Cote d'Ivoire which promotes research in human rights, democracy, among others. Gandhi-Luthuli Peace Institute promotes non-violence as a means of achieving peace, which is done through research dissemination of non-violence theories and principles. Some courses are taught through other subjects, like "Alternative Conflict Resolution, Preventive Diplomacy" are taught under Political Science subject, while inter-ethnic co-existence is taught under Sociology. The Association of African Universities (AAU) and UNHCR have two objectives, which are: to develop African nationals appropriate management skills and culture that is relevant to solving the problems of refugees and humanitarian fields as well as minimizing expatriates, and another objective is to mount courses for conflict prevention management.

In the East Africa a programme curriculum was developed by the Education for Change: Developing Higher Education Programmes in Peace and Human Security in Uganda and Kenya (Pehs Project). The purpose of the project is to enhance capacity \& professional expertise in the field of peace education in the East African 
region. The project is a collaboration of three Institutions University of Nairobi, Kenya, Makerere University, Uganda and Coventry University, UK (Mutoro, H., 2012).

The University of Nairobi launched a Masters Programme in Peace Education (MA in Peace Education) on 29 June 2011, which was motivated by the need to address peace and human security challenges in the region. The programme is aimed at training professionals at the university level who will then spearhead the training of teachers for the course under Kenyan school curriculum.

\section{Impediments to implementation of Peace Education}

Structural violence, armed conflict are major barriers to peace and realization of children's rights at all levels. A research done by Harris et al (1981) in Milwaukee public schools in the United States of America found out although the schools have made commitment to peace education, some factors inhibited its implementation. The findings shows that teacher capacity overload, principal's lack of leadership, lack of financial resources, additional demands , complexity of the model, lack of training on peace education among others are handles that need to be overcome in order to implement peace education. Gbesso, A. (2006), in his study identified several issues that hinder peace education initiatives and in effect inhibit its success. These include the lack of coordination and collaboration between different initiators of Peace Education programmes, failure to have clear goals and objectives, inability to put in place democratic structural organization, especially internal staff. There is also lack of gender balance, where women are conspicuously missing, and lack of financial resources for running the programmes in West Africa, Another obstacle to peace education is lack of up-to date teaching material and also language barrier, especially among the minorities. Lack of political will in cooperating with the selected team. Curriculum that is well adapted to the local needs (Abebe at al., 2006).

Most of the public universities in Kenyan do not offer Peace Education course per se. instead the course is offered as Peace and conflict Studies and in most cases, as elective, as is the case in Egerton University, Kenya. Since post election violence of 2007/8 in Kenya, many universities offer the programme, but mainly at graduate level but many, while in some it is offered as an elective, while some have it in the catalogue but the course is never taught. An interview with Chair (2009), Department of Education and Peace Security, Social Studies 2012), Egerton university, and the Principal Kikuyu Campus, University of Nairobi revealed they have not be able to offer peace education course because of lack of qualified lecturers in the field. Most of the lecturers who have interest in the field have attended some short courses hence are not able to take a course at advance level. They also cited lack of resource materials like books for reference to enable the students to be competent in the subject. Most of the written and available material has been done by foreign scholars and few are written by Africans. The Dons also cited lack of employment for graduates and hence many students opt to go for courses with ready market. There has been poor publicity and communication in many parts of the country on the courses offered by the universities, affecting mainly the people living in the rural areas. The Peace education is seen to be integrated in some subjects which are said to be carriers, like social studies and religious education, which is mainly offered in primary and secondary schools (Ministry of Education, 2009).

The post election violence of 2007/08, led The Kenya Institute of Education (KIE) Ministry of Education and UNICEF to prepare a Peace Education module which was distributed to all District Education Officers, Head teachers and Quality Assurance Officers, to be used in primary schools. There are several factors which negatively influenced the implementation of peace Education curriculum. There is no curriculum for teachers in the university to handle the course. The workload for teachers also might increase, thus over burdening them. The university level also lack trained lecturers, for even those who teach Education, most of them do not have advanced degrees in the subject. There is also lack of training materials. There are no textbooks on the subject, hence rendering the subject ineffective. Most of the university libraries do not have adequate stock of books for the course. There is lack of will by the administration to offer a course that does not attract many students. So in most cases peace education is offered as an elective. In one university they had advertised for Peace and conflict Resolution course at the Master's Level, and the responses were overwhelming, but students were told to do community development instead, because they lacked the relevant teaching material and qualified lecturers. Most of those who demand for the course are those employed by the NGOs but the graduates who would join the public service are not seen to be in need of peace education.

The administrators do not see the need for study the subject because they also believe that Kenya is a relatively peaceful country, hence no need for training on peace. Peace Education and the Culture of Peace and all issues pertaining to conflict resolution, is seen to be strange terminologies used by the UN so as to make people responsive to the international programmes, otherwise the report is that peace has always been offered through "carrier subjects" like the Religious Education, History, Sociology, Social Studies, among others. The methodologies that are familiar in education system need to be revised, because they encourage competition, while peace education advocate for cooperation, grading, critical analysis and discovery of new truths, among other friendly methods. 


\section{Elements of effective to peace education programme}

Elements of effective to peace education programme can be achieved by doing situational analysis before designing the programme, planning for monitoring and evaluation before intervention begins. Enough time for training staff or teachers who will be able to convey peace education skills and concepts. Also encouraging gender and cultural diversity, leads to effective peace education. There should be broad -based support from the community which includes politicians, educators, and public health workers, among others. Incorporation of conflict analysis in community leads to effective peace education. Provision of training materials also promotes peace education.

\section{Conclusion}

As we celebrate the $50^{\text {th }}$ years of scholarship in Africa, we are yet to embrace a culture of peace, where we see each other of much value. Peace education can transform our society from a society living in constant fear of outbreak of war to peace environment, where each culture is respected, every individual live in harmony in the world, sharing the abundant resources God has given mankind to enjoy. Peace education is possible in our universities if we start now to develop and put in place the necessary resources s and learn from others who have goen ahead in the provision of the course. Our future generation need peace so as to reduce the pressures of academic competition, grading and certification system as well as rewarding those who perform better than others, while ignoring those who fail to acquire the minimum set qualification. Peace education is based on cooperation, not competition.

R.D. Laing (1978) puts it this way:'A child born today in the U.K. stands a ten times greater chance of being admitted to a mental hospital than a university.... We are driving mad our children more effectively than we are genuinely educating them. "'There is no way to peace. Peace is the way "Mahatma Gandhi

\section{References}

[1]. Abebe, T.T., Gbesso, A., \& Nyawalo, P. A., 2006 ADDIS 18-20, 2006 Prepared by: Report Of The Working Committee Meeting On: "Peace Education In Africa" Ababa, Ethiopia December

[2]. Bar-Tal, D., (2000) Elusive Nature of Peace Education, School of Education, Tel-Aviv University.

[3]. Brahm, E., (2006) Peace Education Beyond Intractability. Eds. Guy Burgess and Heidi Burgess. Conflict Information Consortium, University of Colorado, Boulder. Posted: July $2006<$ http://www.beyondintractability.org/bi-essay/peace-education Culture of Peace (www.unesco.org/cp)

[4]. Danesh, H.B., (2006) Towards an Integrative Theory of Peace Education Journal of Peace Education Vol.3 No 1

[5]. Dewey ,J.,(1943) - Education and Experience , AmazonOnline Reader 2002, Copyrighted

[6]. Fountain, S., (1995) Working Paper Education Section Programme Division UNICEF New York June 1999

[7]. Hague Appeal for Peace,(2004) Developing Democracy through Peace Education: educating Toward a World Without Violence, Albania, Linza

[8]. Harris I.M. (1988) Peace Education. Jefferson, N.C Farmland Press.

[9]. Harris I., (2003) Peace Education McFarland Press Inc.

[10]. Harris I.M., Glowinski, J., and Perleberg, N., Journal for the Study of Peace and Conflict .Factors That Promote Implementation Of Peace Education Training.

[11]. Harris, I.M., Journal of Peace Education Vol1. No. 1, March 2004. Carfax Publishing .

[12]. Henken, Heather, (2003): In Times of Uncertainty How are Topics of War and Peace Addressed in classroom.

[13]. International Education for Peace (IEP) http://efpinternational.org (Accessed on $28^{\text {th }}$ May 2012)

[14]. ohnson D.W. \&. Johnson.R.,T. (2005) Peace Education in the Classroom: Creating Effective; Peace Education Programs University of Minnesota. Handbook on Peace Education.

[15]. Johnson, D. W., \& Johnson, R. T. (2006). Peace education for consensual peace: The essential role of conflict Resolution. Journal of Peace Education, 3(2), 147-174.

[16]. Kerlinger, F.N (1973): Foundation of Behavioural Research $\left(2^{\text {nd }}\right.$ Ed), Holt Rinliailt and Winston Incl, New York.

[17]. King and Miller C. (2006): Teaching model Non-Violence Transformation Conflict University for peace, Africa Program, Switzerland

[18]. Kothari C.R. (1985): Research Methodology; Methods and Techniques, New Delhi, Wiley Eastern Ltd.

[19]. Kwakwa, E (1997) The Response of African Universities to social Instability and Crises. Paper presented at General Conference, Lusaka, Zambia, 13-17 ${ }^{\text {th }}$ Jan 1997)

[20]. Libresco, A., S \& Balantic, J., Peace Lessons from Around the World - Gloria Levitas Peace and Disarmament Education Tyler,J., and Adam Berry ,A., Time to Abolish War -

[21]. Learning to Abolish War: Book 1, Book 2, Book 3 - Betty A. Reardon and Alicia Cabezudo in http://haguepeace.org/resource/book2/english2pdf.

[22]. Matsuura ,K.,(2001) UNESCO Director- General Today More Than ever a Culture of Peace Maxwell, A., (2002) Catholic Education Office \& NSW Dept of Education, Manuscript

[23]. Monisha B,.(2004) Human Rights education and student self esteem -conception in the Dominican Republic : Teacher College , Colombia University, New York, Journal of Peace education Journal Mutoro, H.,(2011) University of Nairobi: http://education4change.uonbi.ac.ke/

[24]. Okamoto, M., Japanese peace educator www.unescopeaceeducation.org.

[25]. Oslo Coalition supported by Norwegian Foreign Affairs: Salomon. (1999) Peace Education Israel Academic , in : The Concept, Principles, and Practices Around the world , NJ: Lawrence Erlbaum Associates, 2002) 247-258.

[26]. Preamble to the Charter of the United Nations www.peace.ca/unesco/preamble. UNESCO (2000). The Dakar Framework for Action - Education for All: Meeting our Collective Commitments. Adopted by the World Education Forum, Dakar, Senegal, 2628 April 2000

[27]. UNESCO: Peace, Human Security and Conflict Prevention in Africa Proceedings of the UNESCO-ISS Expert Meeting held in Pretoria, South Arica 23-24 July 2001, Edited by Ms Moufida Goucha and Mr. Jakkie Cilliers 
[28]. UNESCO - INEE, November 2005: Inter-Agency Peace Education Programme :Skills for Constructive,7 Place de Fontenoy 75352 Paris $07 \mathrm{SP}$ - France

[29]. UNESCO (1994) Hague Appeal for Peace Global Campaign for Peace Education Campaign Statement

[30]. United Nations Cyberschools/peace/frame htm http://www.educationforpeace.no/english/what.php (accessed on 28th May 2012) http://www.unesco.org/education/efa/edforall/dakframeng.shtml

[31]. UNITED NATIONS, (2000): We the Peoples. The Role of The United Nations in the $21^{\text {st }}$ Century: New Century, New Challenges, Kofi A. Annan former Secretary-General. Published by the United Nations, Department of Public Information, New York, NY 10017 www.un.org

[32]. UNESCO, (1996) International Forum on Education for Non-Violence, Sintra, Portugal,; Guidelines ,for a Plan of Action for UNESCO Interregional Project for Culture of Peace and Non-violence in Educational Institutions; Culture of Peace Programme ,7, Place de Fontenoy,75352 PARIS 07 SP,FRANCE.

[33]. UNESCO :Culture of Peace, Declaration of the 44th session of the International Conference on Education (Geneva, October 1994)

[34]. United Nations Children's Fund (2000): Curriculum Report Card: Working Paper Series Education Section Programme Division, New York, USA.

[35]. First United Nations Special Session on Disarmament, New York, 1978, clause 106) http://haguepeace.org /resources 